\title{
Linear hoof defects in sheep infected with foot-and-mouth disease
}

\author{
A. DeKKer, P. MOONen, J. M. A. Pol
}

\begin{abstract}
During the epidemic of foot-and-mouth disease (FMD) in the Netherlands in 2001, a sheep farm was identified that had been subclinically infected with the disease. The FMD virus genome was detected in 12 of 16 probang samples collected from the sheep and the virus was isolated from four of these samples. Linear defects were observed, 1 to $3 \mathrm{~cm}$ from the coronary band, in the hooves of several of the sheep. The defects were thought to have been caused by the FMD infection. It was thought that the distance of the defects from the coronary band might be an indication of the time since the animals had been infected. To determine the growth rate of the claws of sheep, the growth of the hoof horn of uninfected lambs and ewes was measured; in the lambs the growth rate was $0.44 \mathrm{~mm}$ per day and in the ewes it was $0.29 \mathrm{~mm}$ per day.
\end{abstract}

AFTER 17 years of absence, there were 26 outbreaks of footand-mouth disease (FMD) in the Netherlands in 2001. The epidemic started on a mixed farm with milking goats and veal calves in the centre of the country in a small village called Oene. Owing to the logistic constraints of pre-emptive culling, it was decided to vaccinate all FMD-susceptible animals in a large area around the village. In total, 186,645 cattle, pigs, sheep and goats on 1988 farms were vaccinated (Pluimers and others 2002). On each farm, blood samples were collected before the animals were vaccinated. On only one farm, with 16 ewes and approximately 25 lambs, the sera of all the ewes contained high titres of FMD type $\mathrm{O}$ virusneutralising antibodies.

To study the occurrence of carrier animals, probang samples (Van Bekkum 1959) were collected when the animals were culled; at the same time it was observed that nine ewes and several lambs had linear defects in their hooves, which could have been caused by the FMD infection. Similar linear defects have been described in cattle with FMD (Thomson 1994) and in pigs with swine vesicular disease (Hedger and Mann 1989), but the authors have found no description of the defects in sheep. The growth rates of the claws of cattle (Prentice 1973) and pigs (Johnston and Penny 1989) have been determined, but the growth rate of the claws of sheep has not. It was therefore decided to measure the rate of growth of the hooves of uninfected ewes and lambs.

\section{MATERIALS AND METHODS}

\section{Epidemiological investigation}

The infected farm occupied two separate sites (A and B); the animals had been examined clinically and were sampled repeatedly. For this study the authors consulted the records kept by the inspection service for livestock and meat. During culling it had been observed that nine ewes and several lambs had linear defects in their hooves (Fig 1a), and the distance between the coronary band and the linear defect was estimated.

\section{Sampling}

Blood samples were collected at sites A and B on April 14 and 26, 2001, and additional blood samples were collected at site B on April 19, 2001. Just before they were culled, on April 26, probang samples were collected from the five ewes at site A and from the 16 ewes at site B. The sheep were inspected postmortem for mouth and hoof lesions before they were removed from the premises for rendering. In the laboratory, the probang samples were mixed with an equal volume of minimal essential medium with Earle's salts containing 5 per cent fetal bovine serum and $10^{5} \mathrm{U}$ sodium penicillin $\mathrm{G}$, $0 \cdot 1 \mathrm{~g} / \mathrm{l}$ streptomycin, $2 \mathrm{mg} / \mathrm{l}$ fungizone, $50 \mathrm{mg} / \mathrm{l}$ polymyxin $\mathrm{B}$ and $0.2 \mathrm{~g} / \mathrm{l} \mathrm{kanamycin}$. The mixture was kept in melting ice and mixed vigorously for five minutes with 0.8 times the volume of 1,1,2-trichlorotrifluoroethane. After centrifugation for 15 minutes at $2400 \mathrm{~g}, 200 \mu \mathrm{l}$ of the supernatant was stored at $-70^{\circ} \mathrm{C}$ until it was analysed approximately four weeks later, after the last outbreak was over.

\section{Serological examination}

The sera were screened by ELISA (Chenard and others 2003) and positive samples were tested in the virus neutralisation test described by Dekker and Terpstra (1996).

\section{Virus isolation}

The frozen probang samples were thawed and inoculated on to monolayers of secondary ovine kidney cells in a six-well plate. The inoculum was allowed to adsorb for one hour, after which the monolayers were washed with medium, and $2.5 \mathrm{ml}$ of fresh medium was added. The monolayers were incubated for two days at $37^{\circ} \mathrm{C}$ in a humid atmosphere containing 5 per cent carbon dioxide, and inspected daily for evidence of a cytopathic effect. If a cytopathic effect was observed, or at the end of the observation period, the cultures were frozen, thawed, and the supernatant was again inoculated on to monolayers of secondary ovine kidney cells, and monitored for another two days. Material from both the first and second passages was tested in the antigen detection ELISA described by Roeder and Le Blanc Smith (1987).

\section{Reverse transcriptase-PCR and sequencing}

The reverse transcriptase (RT)-PCR was carried out as described by Moonen and others (2003). RNA was isolated from the probang samples by using standard RNA extraction kits (Roche). A RT-PCR that amplified part of the FMD virus $3 D$ gene was carried out using a LightCycler (Roche). During the PCR, real-time amplification of the specific genome part was measured by two specific internal probes. The first probe (donor) carried a fluorescein label at its $3^{\prime}$ end, and the second probe (acceptor), which attaches to an adjacent part of the amplified product, carried another label (LC Red 640) at its $5^{\prime}$ end. A signal is emitted if both probes hybridise on the same sequence. For sequencing of the $1 D$ gene, a second RT-PCR was used, following the standard methods described by Knowles and Samuel (1998).

\section{Animal experiment}

Five ewes and five newborn lambs were selected from the sheep flock kept at the authors' institute. At the start of the
Veterinary Record (2005) $156,572-575$

A. Dekker, DVM, $\mathrm{PhD}$ MSc,

P. Moonen, $\mathrm{PhD}$, Central Institute for Animal Disease Control, CIDC-Lelystad, PO Box 2004, 8203 AA Lelystad, The Netherlands J. M. A. Pol, PhD, Jol 30-05, 8243 HA Lelystad, The Netherlands 

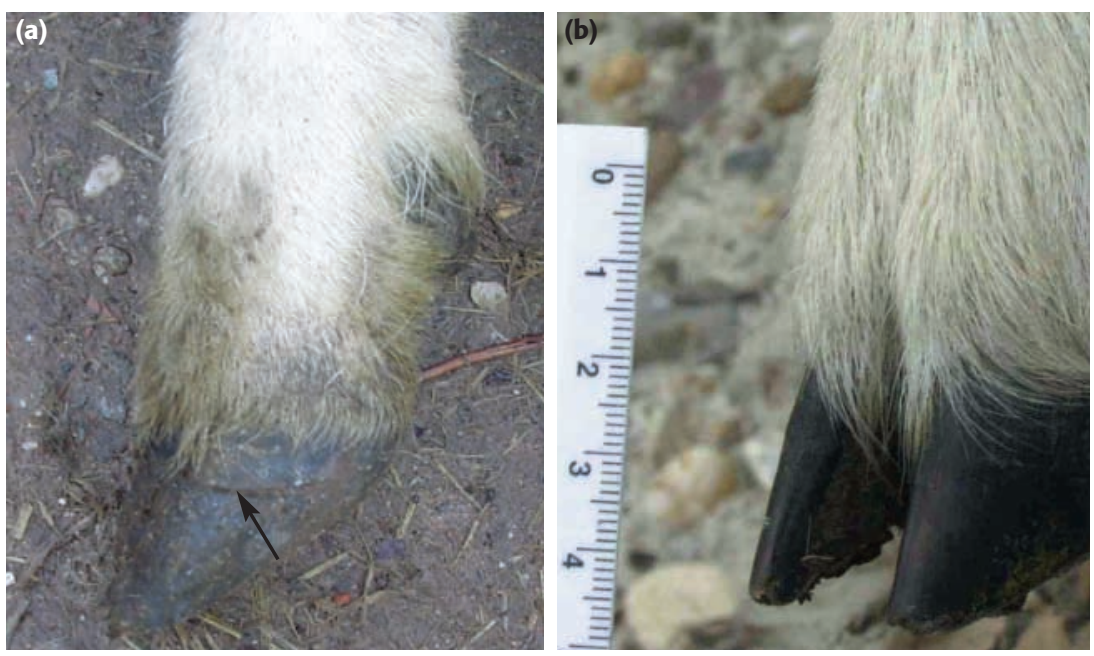

FIG 1: (a) Linear defect (arrow) observed in the claw of a sheep at site B; (b) claw of a normal sheep, for comparison

experiment, a small groove parallel to the coronary band was made, using a hacksaw, in the side of the right lateral claw on the front and hind legs. The distance from this groove to the coronary band was measured with a ruler when the groove was made and three, 10,17, 24, 31 and 59 days later. The distance measured was rounded to the nearest $\mathrm{mm}$.

\section{Statistical analysis}

The data from the animal experiment were analysed by linear regression, using S-Plus (Insightful), and assuming no growth on the day the groove was made. To test whether there were differences in growth rate between the front and hind feet, or between ewes and lambs, these factors were added to the model, and the likelihood-ratio test was used to check whether their inclusion resulted in a better model. To estimate the time of infection, reverse regression was used (Seber 1977).

\section{RESULTS}

\section{Epidemiological investigation}

A small flock of 34 ewes and one ram had been kept until March 16, 2001 in two meadows at site A. Moving pregnant

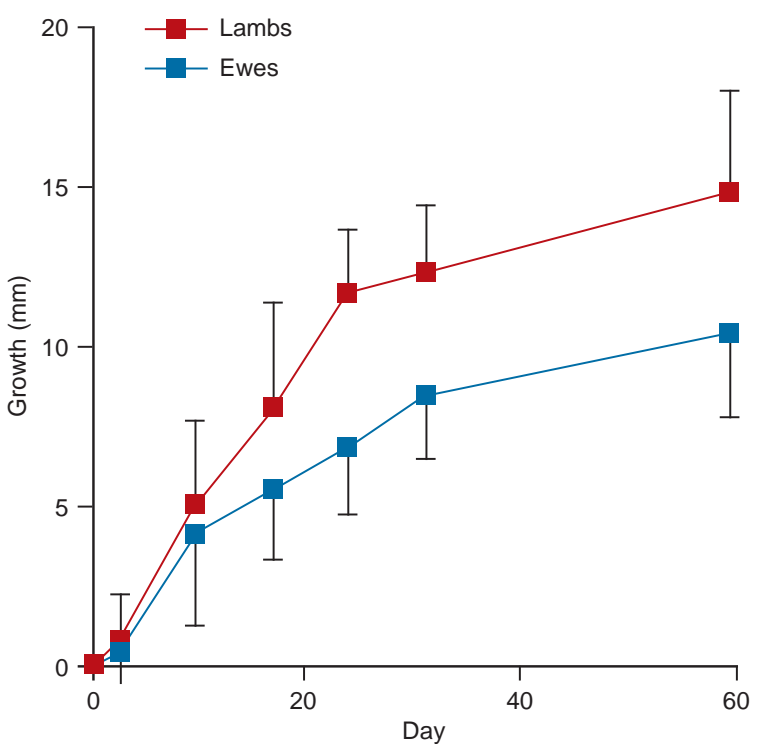

ewes had become a problem after the implementation of a standstill on the movement of small ruminants on February 22 . The farmer was granted an exemption on the standstill for the transport of his pregnant ewes, and he transported 16 ewes, in two batches of eight, to a small stable at site B, approximately $20 \mathrm{~km}$ south of site A, on March 16, under the supervision of an official employee of the inspection service for livestock and meat. The farmer used his own vehicle, which had been disinfected before use under the supervision of an official employee of the inspection service for livestock and meat. Owing to the size of the vehicle and the fact that the exemption was valid for only one day, the farmer was unable to transport all the sheep to site B. On April 14, most of the animals at site A and all the animals at site B were vaccinated against FMD and blood samples were collected. Because there was a positive serological response in the ELISA, an official veterinarian checked all the sheep at site B on April 19; the official veterinarian observed no clinical signs of FMD, either when the sheep were vaccinated or on April 19.

When the animals were examined postmortem on April 26, a linear defect was observed (Fig 1) 1 to $3 \mathrm{~cm}$ from the coronary band of one or more hooves of nine of the 16 ewes at site B. The linear defects, caused by growth retardation or coronary band lesions, were 1 to $2 \mathrm{~mm}$ deep and most easily observed at the side of the hoof, although in most cases they extended to the medial part of the hoof. All the sheep at site A were inspected, but no hoof lesions were observed. The tracing team of the inspection service for livestock and meat considered indirect contact with a previously infected herd by the owner's veterinarian to have been the most likely route of introduction of FMD. Site B had been visited by the veterinarian on March 17, 21 and 28, 2001, but there was no evidence that the veterinarian had been in contact with a known outbreak of FMD.

\section{Serological results}

No antibodies to FMD type $\mathrm{O}$ were detected by ELISA in the 12 samples collected from site A on April 14. In contrast, the samples collected at site B were positive by ELISA and had $\log _{10}$ virus neutralisation titres ranging from 1.65 to 2.7 (mean 2.3 ); when this site was sampled again, five days later, the ELISA and virus neutralisation tests both produced positive results, with $\log _{10}$ virus neutralisation titres ranging from $1 \cdot 8$ to $2 \cdot 85$. The serum samples collected at site A on April 26 had titres ranging from $<0 \cdot 6$ to 1.95 .

\section{Virus isolation and RT-PCR}

None of the five probang samples collected at site A was positive by either virus isolation or RT-PCR. At site B, however, four of the 16 probang samples were positive by virus isolation and 12 were positive by RT-PCR. Sequencing the $1 D$ region of the isolate showed that its sequence was identical to the $1 D$ sequences found in nine other outbreaks in 2001.

\section{Animal experiment}

Fig 2 shows the average growth of horn observed in the uninfected ewes and their lambs. A linear regression model was applied to the observations from day 0 to day 31 , because the curve appeared to flatten after day 31 . No significant difference was observed between the growth of the horn on the front and hindlegs, and the average horn growth was therefore calculated. However, there was a significant difference between the growth of horn in the ewes and lambs $(\mathrm{P}<0 \cdot 01)$. In the ewes, the average rate of growth was $0.29 \mathrm{~mm} /$ day $(95$ per cent confidence interval (CI) 0.26 to $0.32 \mathrm{~mm} /$ day), and in the lambs it was $0.44 \mathrm{~mm} /$ day ( 95 per cent CI $0 \cdot 41$ to 0.47 $\mathrm{mm} /$ day). Using inverse regression, the 95 per cent prediction interval for the time of infection was calculated for the sheep at site B (Table 1). 


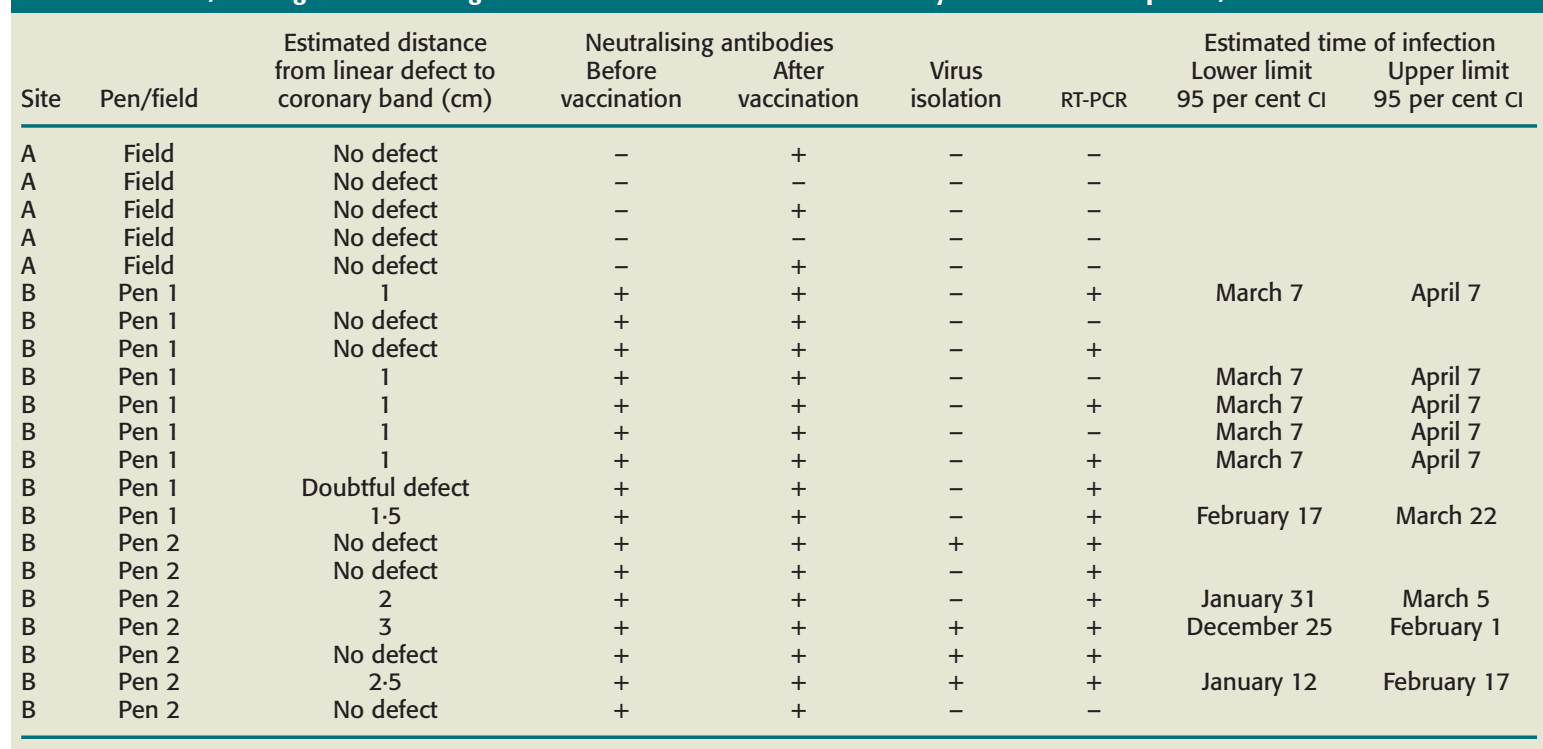

RT-PCR Reverse-transcriptase PCR, CI Confidence interval

\section{DISCUSSION}

The aim of the visit to the farm when the sheep were culled was to determine whether carrier sheep could be detected in a flock after a natural infection with FMD. On the basis of the serological evidence it was clear that the sheep at site B had been in contact with FMD virus type O. However, neither the farmer nor the employees of the inspection service of livestock and meat had seen clinical signs of the disease. It is known that even after experimental infection clinical lesions are observed in a limited number of infected sheep (Sharma and others 1981, Gibson and Donaldson 1986), and small lesions can easily be overlooked. The infection of the animals was confirmed by virus isolation and RT-PCR of the probang samples. At site B, 12 of the 16 probang samples taken from the serologically positive ewes were positive by RT-PCR and four of these 12 samples were positive by virus isolation. On the farm of origin (that is, site A), none of the probang samples contained FMD virus or its genome. The persistence of FMD infection in sheep has been documented previously after experimental infection (Burrows 1968, McVicar and Sutmoller 1968, Alexandersen and others 2002), and also after natural outbreaks (Sharma and others 1981, 1982).

It was considered that the linear defects observed in the hooves of several sheep were most probably due to the FMD infection, and it was thought that their distance from the coronary band might be an indication of the time since the farm had been infected. The rates of growth of the horn of healthy ewes and lambs were therefore measured. However, the hooves of the ewes and lambs did not grow at the same rate throughout the experiment (Fig 2). On the basis of the anatomy of the hoof, this can be explained because the hoof becomes wider distally, so that the horn produced at the coronary band has to spread out. For this reason only the measurements of hoof growth up to 31 days were used in the linear regression model, under the assumption that the lesions observed in sheep at site B were most probably no more than 31 days old. If the lesions at the infected farm had been more than 31 days old, the interval between infection and observation would have been underestimated. The analysis showed that the hoof horn of the lambs grew significantly more quickly than that of the ewes. Similar differences have been reported in pigs (Johnston and Penny 1989) and cattle (Prentice 1973) of different ages. As in the study in pigs
(Johnston and Penny 1989), there was no significant difference between the growth rates of the horn on the front and hindlegs. The estimates of the horn growth rates resulted in wide prediction intervals for the time of infection. This was mainly caused by the variation between animals, but was also due to inaccuracy of measurement; the latter was caused by rounding the distance to the nearest $\mathrm{mm}$ and the difficulty in identifying the coronary band exactly.

The linear defects were observed not only in the hooves of nine ewes but also in the hooves of several lambs on the infected farm. Data on the defects in the lambs were not recorded, because the lambs were not uniquely identified; for the same reason, the lambs had not been sampled for serology. The linear defects were not always present on all the hooves of the same animal, indicating that they were not caused by dietary deficiencies. No hoof lesions were observed on the farm of origin ( site A). The distance from the lesion to the coronary band in several of the affected ewes and lambs was similar, suggesting that the defects were caused by the previous FMD infection, which was the only known difference between the sheep on the two sites. Linear defects like those observed in these sheep have been described in cattle with FMD (Thomson 1994), and in pigs with swine vesicular disease (Hedger and Mann 1989), but no reports of similar defects in sheep have been found.

The distances between the linear defects and the coronary band of the sheep at site B were only estimated, but applying the linear regression model to these estimates suggested that five of the ewes had been infected between March 13 and April 10. In some of the ewes, the distance between the defect and the coronary band was estimated to be larger, and if these defects had been caused by the FMD infection the estimated time of infection would have been before the ewes were transported to site B on March 16. Infection before this date is very unlikely, because none of the ewes tested at site A had antibodies to FMD when they were vaccinated, and no FMD virus or genome could be detected in the probang samples from these sheep. Some of the defects may therefore not have been caused by FMD infection, or the distance between the defect and the coronary band may have been overestimated. Alternatively, there may be a difference between the growth rate of the horn in infected and uninfected sheep. Infection experiments with lambs and ewes would be required to investigate this possibility. 
These results confirm previous findings that FMD carriers can be found among naturally infected sheep, and show that the linear defects observed in the hoof horn of recovered cattle (Thomson 1994) can also occur in recovered sheep. On the basis of the observed growth rate of the horn in the ewes and lambs, the defects could be used to estimate when the affected sheep were infected with FMD. In the present study, the difference between the postulated time of infection, based on the estimated distance between the linear defect and the coronary band, and the epidemiological and serological data, was probably caused by overestimation of the distance. The authors therefore recommend that veterinarians should consider taking a ruler with them when investigating suspected FMD outbreaks on sheep farms to enable measurement of the distance of any such lesions on the feet of sheep examined.

\section{References}

ALEXANDERSEN, S., ZHANG, Z., REID, S. M., HUTCHINGS, G. H. \& DONALDSON, A. I. (2002) Quantities of infectious virus and viral RNA recovered from sheep and cattle experimentally infected with foot-andmouth disease virus O UK 2001. Journal of General Virology 83, 1915-1923 BURROWS, R. (1968) The persistence of foot-and-mouth disease virus in sheep. Journal of Hygiene 66, 633-640

CHENARD, G., MIEDEMA, K., MOONEN, P., SCHRIJVER, R. S. \& DEKKER, A. (2003) A solid-phase blocking ELISA for detection of type O foot-andmouth disease virus antibodies suitable for mass serology. Journal of Virological Methods 107, 89-98

DEKKER, A. \& TERPSTRA, C. (1996) Prevalence of foot-and-mouth disease antibodies in dairy herds in the Netherlands four years after vaccination. Research in Veterinary Science 61, 89-91

GIBSON, C. F. \& DONALDSON, A. I. (1986) Exposure of sheep to natural aerosols of foot-and-mouth disease virus. Research in Veterinary Science 41, 45-49

HEDGER, R. S. \& MANN, J. A. (1989) Swine vesicular disease virus. In Virus Infections of Porcines. Ed M. B. Pensaert. Amsterdam, Elsevier Science. pp 241-250
JOHNSTON, A. M. \& PENNY, R. H. (1989) Rate of claw horn growth and wear in biotin-supplemented and non-supplemented pigs. Veterinary Record $\mathbf{1 2 5}$, 130-132

KNOWLES, N. J. \& SAMUEL, A. R. (19998) RT-PCR and sequencing protocols for the molecular epidemiology of exotic virus diseases of animals. www.iah. bbsrc.ac.uk/virus/picornaviridae/aphthovirus/protocol.pdf. Accessed April 14,2005

MCVICAR, J. W. \& SUTMOLLER, P. (1968) Sheep and goats as foot-andmouth disease carriers. Proceedings of the Annual Meeting of the United States Animal Health Association 72, 400-406

MOONEN, P., BOONSTRA, J., HAKZE-VAN DER HONING, R., BOONSTRA-LEENDERTSE, C., JACOBS, L. \& DEKKER, A. (2003) Validation of a LightCycler-based reverse transcription polymerase chain reaction for the detection of foot-and-mouth disease virus. Journal of Virological Methods 113, $35-41$

PLUIMERS, F. H., AKKERMAN, A. M., VAN DER WAL, P., DEKKER, A. \& BIANCHI, A. (2002) Lessons from the foot and mouth disease outbreak in the Netherlands in 2001. Revue Scientifique et Technique - Office International des Epizooties 21, 711-721

PRENTICE, D. E. (1973) Growth and wear rates of hoof horn in Ayrshire cattle. Research in Veterinary Science 14, 285-290

ROEDER, P. L. \& LE BLANC SMITH, P. M. (1987) Detection and typing of foot-and-mouth disease virus by enzyme-linked immunosorbent assay: a sensitive, rapid and reliable technique for primary diagnosis. Research in Veterinary Science 43, 225-232

SEBER, G. A. F. (1977) Straight-line regression. In Linear Regression Analysis. New York, John Wiley \& Sons. pp 177-213

SHARMA, S. K., SINGH, P. P. \& MURTY, D. K. (1981) Foot and mouth disease in sheep and goats: an iceberg infection. Indian Veterinary Journal $\mathbf{5 8}$ 925-928

SHARMA, S. K., SINGH, P. P. \& MURTY, D. K. (1982) Biological properties of carrier strains of foot-and-mouth disease virus type 'O' isolated from sheep and goats. Indian Journal of Animal Sciences 52, 30-34

THOMSON, G. R. (1994) Foot and mouth disease. In Infectious Diseases of Livestock with Special Reference to Southern Africa. Eds J. A. W. Coetzer, G. R. Thomson, R. C. Tustin. Cape Town, Oxford University Press. pp 825852

VAN BEKKUM, J. G. (1959) Observation on the carrier state of cattle exposed to FMDV. Tijdschrift Voor Diergeneeskunde 84, 1159-1164 